UDC $547.873 ; 544.433 .21$

\title{
SYNTHESIS OF COMPOUNDS \\ OF THE 1,2,4-AMINOTRIAZINES SERIES
}

\section{СИНТЕЗ СОЕДИНЕНИЙ РЯДА 1,2,4-АМИНОТРИАЗИНОВ}

\author{
S.R. Faizullina, D.R. Sadykova, M.S. Klyavlin,
} D.U. Rysaev, A.K. Mazitova

FSBEI of HPE "Ufa State Petroleum Technological University”, Ufa, the Russian Federation

Файзуллина С.Р., Садыкова Д.Р., Клявлин М.С., Рысаев Д.У., Мазитова А.К.

ФГБОУ ВПО «Уфимский государственный нефтяной технический университет», Уфа, Российская Федерация

e-mail: sveta-mol86@mail.ru

Abstract. Thestreamlined synthesis of compounds with wide spectrum of essential properties is prospective lines of development of chemistry of nitrogen containing heterocyclic compounds. Triazines hold a specific place among the great variety of nitrogen containing heterocyclic compounds. Derivatives of unsymmetrical triazines demonstrate a large range of bioactive action, they were offered in the quality of herbicides, plant growth regulators, insecticides, antifungal, acaricide, pharmaceutical and veterinary preparations, stabilizer-antioxygen of polymers and also as corrosion inhibitor. Compounds of 1,2,4-triazinones series are widely reported in the publications, but unsymmetrical triazines particularly their acyl and amino derivatives haven't been studied detailed. Especially there are not many articles about route for the synthesis of acyl and amino 
derivatives. Known methods of synthesis based on the hardly accessible materials. For this reason developing of new methods of unsymmetrical triazines synthesis on the base of available petrochemical raw materials and investigation of their properties and fields of their application are promising direction. The reactions of aminoguanidine and hydrazine hydrate with carboxylic acids derivative, that led to 1,2,4-triazines with the amino group in the different position were studied. 3-Amino-1,2,5,6tetrahydro-1,2,4-trizain-6-on obtained by interaction of chloracetylchloride and unsubstituted aminoguanidine. 4-amino-1,4,5,6-tetrahydro-1,2,4triazin-5-on forms in the reaction of monochloracetic acid with hydrazine hydrate. 4-Amino-1,2,5,6-tetrahydro-1,2,4-trizain-5,6-dion was synthesized from diethyl oxalate, hydrazine hydrate and formic acid. On the base of synthesized amino-triazines and isobutyryl chloride corresponding amides were obtained. Physico-chemical constants of obtained compounds are shown. It is determined that data of elemental analysis of obtained compounds correspond to theoretically calculated values in range of standard deviation.

Аннотация. Перспективным направлением развития химии азотсодержащих гетероциклических соединений является направленный синтез веществ, обладающих широким спектром практически ценных свойств. Среди многообразия азотсодержащих гетероциклических соединений особое место занимают триазины. Производные несимметричных триазинов проявляют довольно насыщенный спектр биологически активного действия, они предложены в качестве гербицидов и регуляторов роста растений, инсектицидов и фунгицидов, акарицидов, лекарственных и ветеринарных веществ, стабилизаторов-антиоксидантов полимеров, а 
также ингибиторов коррозии. В литературе широко освещены соединения ряда 1,2,4-триазинонов, однако несимметричные аминотриазины, в частности, их ацил- и аминопроизводные изучены недостаточно подробно. Особенно мало публикаций о методах их синтеза. Известные способы получения соединений этого ряда основаны на использовании труднодоступного сырья. Поэтому перспективным направлением является разработка методов получения несимметричных аминотриазинов на основе доступного нефтехимического сырья, а также исследование некоторых свойств и возможных областей их применения. В работе приводятся результаты исследования реакций аминогуанидина и гидразингидрата с производными карбоновых кислот, приводящие к 1,2,4-триазинам с аминогруппой в разных положениях. Установлены условия (мольное соотношение реагентов, растворитель, температура) максимального выхода целевых продуктов. При взаимодействии хлорацетилхлорида и незамещенного аминогуанидина образуется 3-амино-1,2,5,6тетрагидро-1,2,4-триазин-6-он. В реакции монохлоруксусной кислоты с гидразингидратом образуется 4-амино-1,4,5,6-тетрагидро-1,2,4триазин-5-он. 4-Амино-1,4,5,6-тетрагидро-1,2,4-триазин-5,6-дион получен из диэтилоксалата, гидразингидрата и муравьиной кислоты. На основе синтезированных аминотриазинов и хлорангидрида изомасляной кислоты получены соответствующие амиды. Приведены физико-химические константы полученных соединений. Установлено, что данные элементного анализа синтезированных соединений соответствуют теоретически рассчитанным значениям в пределах обычных отклонений. 
Key words: 3-Amino-1,2,5,6-tetrahydro-1,2,4-trizain-6-on, 4-amino1,4,5,6-tetrahydro-1,2,4-triazin-5-on, 4-Amino-1,2,5,6-tetrahydro-1,2,4trizain-5,6-dion, 3-isobutylamido-1,2,5,6-tetrahydro-1,2,4-trizain-6-on, 4isobutylamido -1,2,5,6-tetrahydro-1,2,4-trizain-5,6-dion, 4- isobutylamido 1,2,5,6-tetrahydro-1,2,4-trizain-5-on.

Ключевые слова: 3-амино-1,2,5,6-тетрагидро-1,2,4-триазин-6он, 4-амино-1,4,5,6-тетрагидро-1,2,4-триазин-5-он, 4-амино-1,4,5,6тетрагидро-1,2,4-триазин-5,6-дион, 3-изобутиламидо-1,2,5,6тетрагидро-1,2,4-триазин-6-он, 4-изобутиламидо-1,4,5,6-тетрагидро1,2,4-триазин-5-он, 4-изобутиламидо-1,4,5,6-тетрагидро-1,2,4-триазин5,6-дион.

Derivatives of unsymmetrical triazines are a prospective class of heterocyclic compounds. Their aminoderivatives are not great studied but they are attractive in relation to searching for new plant growth regulators, herbicides, antifungal, acaricide, pharmaceutical and veterinary preparations [1-5].

In this work the results of an investigation of new methods of synthesis and of the chemical-physical properties of 1,2,4-triazine's derivatives with aminogroups in 3-, and 4- positions are shown.

3-Amino-1,2,5,6-tetrahydro-1,2,4-trizain-6-on (I) was obtained from chloracetylchloride and unsubstituted aminoguanidine.

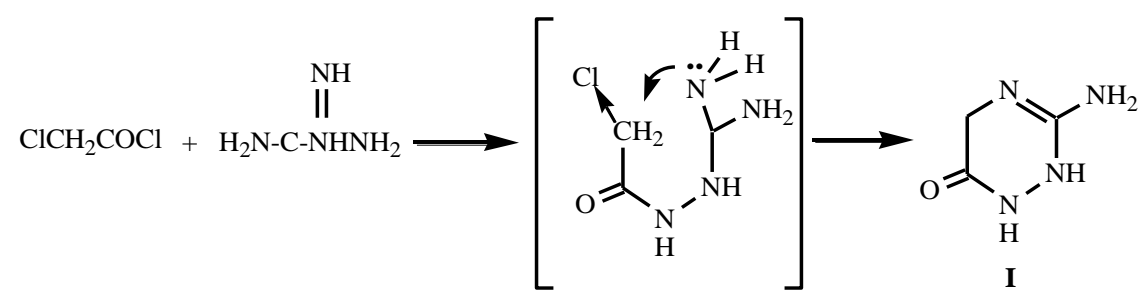

Chloroacetylation proceed on the more basic $\mathrm{N}^{1}$ atom, produced 1chloracetylaminoguanidine cyclizes into triazine as a result of nucleophilic 
attack of the nitrogen atom of the amino group of the methylene carbon atom in the molecule of the intermediate compound which we couldn't isolate.

The reaction proceeds with the highest yield in the glacial acetic acid in the presence of sodium acetate as a cyclizing agent, in case of the equimolar ratio of initial reagents and room temperature.

When using substituted aminoguanidines (guanilhydrazones of aldehydes and ketones) substituted 2-hydrazinoimidazolin-4-ones was obtained instead of the expected aminoderivatives of 1,2,4-trizain [6].

4-Amino-1,2,5,6-tetrahydro-1,2,4-trizain-5,6-dion (II) was derived from diethyl oxalate, hydrazine hydrate and formic acid. Synthesis was carried out in two stages.
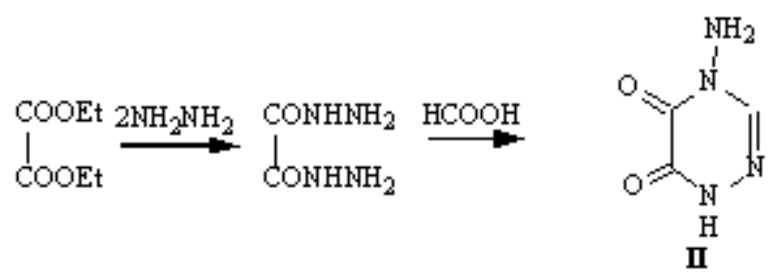

In the first stage oxalic dihydrazide with $75 \%$ yield was obtained. In the second stage 4-amino-1,2,5,6-tetrahydro-1,2,4-trizain-5,6-dion was obtained by boiling of $10 \%$ excess of oxalic dihydrazide with formic acid in the dimethylformamide during 3 hours with maximum yield.

4-amino-1,2,5,6-tetrahydro-1,2,4-trizain-5-on (III) was obtained on a base of ethyl monochloroacetate. In the first stage monochloroacetic acid hydrazide was synthesized. In the second stage hydrazino acetic acid hydrazide was synthesized. The desired product (III) was prepared by boiling hydrazino acetic acid hydrazide with two and half of excess of formic acid until solid residue. 


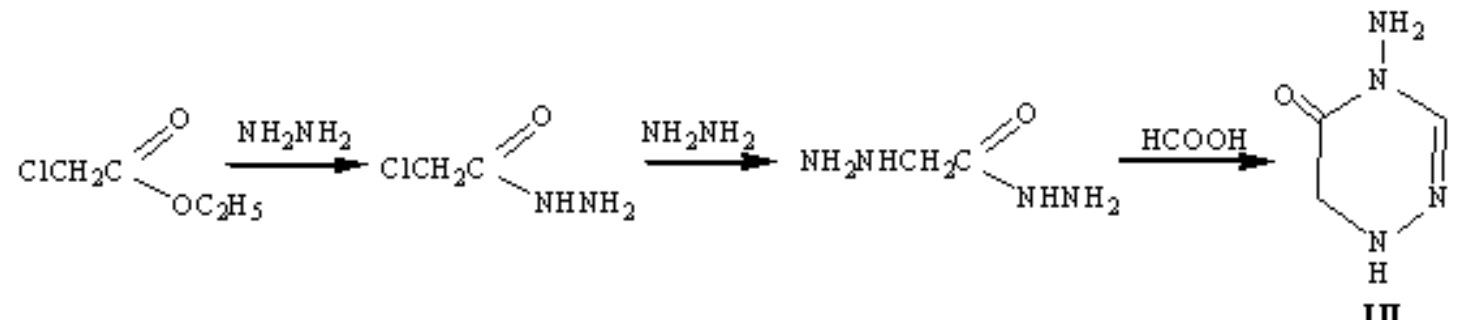

In the IR spectra strong absorption lines of triazine's ring at 1500$1700,600-800 \mathrm{~cm}^{-1}$ are observed. In the mass-spectrums of synthesized triazines, intensive molecular peaks, which coincide with the calculated weight o molecular mass, present and give evidence that the supposed structure corresponds to the real structure [7].

Corresponding amides (IV-VI) were obtained by interaction of aminotriazines (I-III) with isobutyryl chloride. Synthesis was carried out in glacial acetic acid with using $5 \%$ excess of isobutyryl chloride at room temperature.

\section{Experimental part}

The ${ }^{1}$ HNMR-spectra were recorded on the Bruker DPX-400 spectrometer in $\mathrm{CDCl}_{3}$, The IR-spectra - on Specord 75-IR spectrometer in paraffinic oil, the mass spectra - on KRATOS-80 mass-spectrometer.

Hydrazino acetic acid hydrazide. A mixture of 0,2 moles of hydrazine hydrate and 0,1 mole of monochloroacetic acid hydrazide in 10 $\mathrm{ml}$ of ethanol was exposed for 3 hours at $80^{\circ} \mathrm{C}$. The reaction mixture was treated with hexane, evaporated and was treated with 6n solution of hydrochloric acid.

3-Amino-1,2,5,6-tetrahydro-1,2,4-trizain-6-on (I). 5,6g (0,05mole) of chloracetylchloride was put in drop by drop into the mixture of $6,7 \mathrm{~g}$ $(0,05$ mole $)$ aminoguanidine bicarbonate, $4,1 \mathrm{~g}(0,05 \mathrm{~mole})$ of sodium acetate and $10 \mathrm{ml}$ of glacial acetic acid. At this time, the reaction mixture 
warmed up to $70^{\circ} \mathrm{C}$. The mixture was cooled to room temperature and was added to the $23 \%$ soda solution. The precipitated solid was filtrated and washed in water and acetone and air-dried. Yield $75 \%, \mathrm{mp} 105-106^{\circ} \mathrm{C}$. IR, $v, \mathrm{~cm}^{-1}: 3240(\mathrm{NH}), 1520(\mathrm{CO}), 1680$ (triazine ring). ${ }^{1} \mathrm{HNMR}, \delta, 8.97(3 \mathrm{H}$, $\left.\mathrm{NH}_{\text {triazin }} 2, \mathrm{NH}_{\text {amine }}\right), 8.45\left(1 \mathrm{H}, \mathrm{NH}_{\text {triazin }} 1\right)$. Found, \%: C 31.37; $\mathrm{H} 5.30 ; \mathrm{N}$ 49.12. $\mathrm{C}_{3} \mathrm{H}_{6} \mathrm{~N}_{4} \mathrm{O}$. Requires, \%: C 31.57; H 5.26; N 49,12. M 114.13.

4-Amino-1,2,5,6-tetrahydro-1,2,4-trizain-5,6-dion $\quad$ (II). $2 \mathrm{ml}$ $(0,045$ mole $)$ of $95 \%$ formic acid was added drop by drop to the solution of $5,9 \mathrm{~g}(0,05$ mole $)$ oxalic dihydrazide in $10 \mathrm{ml}$ of DMFA and was heated for 3 hours with refluxing, $20 \mathrm{ml}$ cold water was added. The precipitate was filtrate and recrystallized from water and air-dried. Yield 47\%, mp 224$225^{\circ} \mathrm{C} . \mathrm{IR}, v, \mathrm{~cm}^{-1}: 3300(\mathrm{NH}), 1460(\mathrm{CO}), 1530$ (triazine ring). ${ }^{1} \mathrm{HNMR}, \delta$, $12.84\left(1 \mathrm{H}, \mathrm{NH}_{\text {triazin }} 1\right), 6.00\left(2 \mathrm{H}, \mathrm{NH}_{\text {amin }}\right)$. Found, \%: C 28.15; H 3.11; N 43.18. $\mathrm{C}_{3} \mathrm{H}_{4} \mathrm{~N}_{4} \mathrm{O}_{2}$. Requires, \%: C 28.13; H 3.14; N 43,74. M 128.09.

4-Amino-1,2,5,6-tetrahydro-1,2,4-trizain-5-on (III). Solution of $5,3 \mathrm{~g}(0,05 \mathrm{~mole})$ hydrazino acetic acid hydrazide in $2 \mathrm{ml}(0,045 \mathrm{~mole})$ of $85 \%$ formic acid was boiled until formic acid removing, then 14,4 (0.08 mole) water was added and dried. Solid residue was washed by acetone and air-dried. Yield 93\%, mp 149-151 ${ }^{\circ} \mathrm{C}$. IR, v, $\mathrm{cm}^{-1}$ : 3400(NH), 1460 (CO), 1630(triazine ring). ${ }^{1} \mathrm{HNMR}, \delta, 6.47\left(3 \mathrm{H}, \mathrm{NH}_{\text {triazin }} 2, \mathrm{NH}_{\text {amine }}\right), 9.90(1 \mathrm{H}$, $\left.\mathrm{CH}_{\text {arom}}\right)$. Found, \%: C 31.57; $\mathrm{H} 5.31 ; \mathrm{N}$ 49.12. $\mathrm{C}_{3} \mathrm{H}_{6} \mathrm{~N}_{4} \mathrm{O}$. Requires, \%: C 31.57; H 5.26; N 49.10. M 114.11.

Isobutylamido-1,2,5,6-tetrahydro-1,2,4-trizain (IV, V, VI). 0,05 moles of chloroanhydride of isobutyric acid was added drop by drop to the 0,05 moles of triazin (I, II or III) in $10 \mathrm{ml}$ of glacial acetic acid. The obtained precipitate was filtered and washed in water.

3-Isobutylamido-1,2,5,6-tetrahydro-1,2,4-trizain-6-on (IV).Yield $80 \%$, mp 113-115 $\mathrm{C}$. IR, v, $\mathrm{cm}^{-1}: 3420(\mathrm{NH}), 1660$ (CO), 1620(triazine 
ring). ${ }^{1} \mathrm{HNMR}, \delta, 8.96\left(2 \mathrm{H}, \mathrm{NH}_{\text {triazin }} 2\right), 2.80(3 \mathrm{H}, \mathrm{Me}), 2.78(3 \mathrm{H}, \mathrm{Me})$. Found,\%: C 45.62; $\mathrm{H}$ 6.57; N 30.39. $\mathrm{C}_{7} \mathrm{H}_{12} \mathrm{~N}_{4} \mathrm{O}_{2}$ Requires, \%: C 45.64; $\mathrm{H}$ 6.56; N 30,41. M 184.20.

\section{4-Isobutylamido-1,2,5,6-tetrahydro-1,2,4-trizain-5,6-dion} Yield 78\%, mp 242-244 ${ }^{\circ} \mathrm{C}$. IR, $v, \mathrm{~cm}^{-1}: 3440(\mathrm{NH}), 1610$ (CO), 1650(triazine ring). ${ }^{1} \mathrm{HNMR}, \delta, 9.9(\mathrm{H}, \mathrm{CH}), 12.89\left(\mathrm{H}_{,} \mathrm{NH}_{\text {triazin }}\right), 2.84(3 \mathrm{H}$, $\mathrm{Me}), 2.86(3 \mathrm{H}, \mathrm{Me})$. Found, \% : C 42.45; $\mathrm{H}$ 5.06; $\mathrm{N}$ 28.22. $\mathrm{C}_{7} \mathrm{H}_{10} \mathrm{~N}_{4} \mathrm{O}_{3}$ Requires, \%: C 42.43; H 5.08; N 28.27. M 198.128.

4-Isobutylamido-1,2,5,6-tetrahydro-1,2,4-trizain-5-on (III). Yield

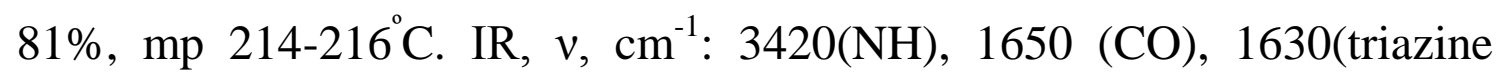
ring). ${ }^{1} \mathrm{HNMR}, \delta, 9.9(\mathrm{H}, \mathrm{CH}), 12.40\left(\mathrm{H}_{,} \mathrm{NH}_{\text {triazin }}\right), 2.88(3 \mathrm{H}, \mathrm{Me}), 2.88(3 \mathrm{H}$, Me). Found,\% C 45.65; $\mathrm{H}$ 6.52; $\mathrm{N}$ 30.38. : $\mathrm{C}_{7} \mathrm{H}_{12} \mathrm{~N}_{4} \mathrm{O}_{2}$ Requires, \%: C 45.64; H 6.56; N 30,41. M 184.20.

\section{Conclusion}

As the result the data of elemental analysis corresponds to the calculated data in the range of standard deviation. Obtained compounds were delivered for testing in the quality of corrosion inhibitor.

\section{References}

1. Mironovich L.M., Promonenko V.K., 1,2,4-triazines. // Results of science and engineering. VINITI, Organic chemistry ser. 1990, № 22. 267p. [in russian].

2. Aminova G.K., Kudayarova R.R., Bulgakov A.K., Mazitova A.K. Baskirskii khimicheski zhurnal. 2004. Vol. 11, № 4 pp 15 -16. [in russian]. 
3. Saint-Klar E. Sh., Hamaev V.H., Tyurina L.A., Mazitova A.K. Study of biological activity of Asymmetric triazines // Baskirskii khimicheski zhurnal. - 2002. Vol. 9, № 1 pp 88 -89. [in russian].

4. El - Telbani E.M., Swettem R.H., Narwar G.A. Easy synthesis of easy synthesis 6-hetaryl[1,2,4]-triazolo-[3,4-b]-thiadiazoles and 7hetaryl[1,3,4]-thiadiazole- [2,3-c]- [1,2,4]-triazines, with fungicidal activity // Journal of Organic Chemistry - 2007, Vol. 43, Vol. № 12 pp.1813-1818. [in russian].

5. Faizullina S.R., Kalistratova T.A., Builova E.A., Galieva D.R., Mazitova A.K. Synthesys of N-acylated derivatives of some triazines // Baskirskii khimicheski zhurnal. - 2012. Vol. 19, № 3, pp. 92 - 94. [in russian].

6. Seint-Kler E., Hamaev V.H., Mazitova A.K., Gorelov V.S. Unsymmetrical triazines. Interaction of chloracetylchloride with aminoguanidine and semicarbazides. // Proceedings of the VI International scientific-technical conference «ASF-2002». Ufa, 2002. pp. 204-205. [in russian].

7. Galieva D.R., Ingram I.S., Aminva G.K. Spectral charachteristics of aminoderivatives // Proceedings of the XXI International scientifictechnical conference «Reaktiv-2008». Ufa: Reaktiv, 2008. - p. 78-80. [in russian]. 


\section{Список используемых источников}

1. Миронович Л.М., Промоненков В.К. 1,2,4-триазины. // Итоги науки и техники. ВИНИТИ. Сер. Органическая химия. 1990. №22. C. 267.

2. О биологической активности 1,2,4 -триазиндинонов -5,6 / Аминова Г.К. и др. // Башкирский химический журнал. 2004.Т. 11, №4 C. $15-16$.

3. Исследование биологической активности несимметричных триазинов / Сэйнт-Клэр Э.Ш. и др. // Башкирский химический журнал. 2004. T. 9, №2. C.88-89.

4. El-Telbani E.M., Swettem R.H., Nawwar G.A.M. Легкий синтез 6-гетарил[1,2,4]-триазоло- $\quad[3,4-b]$-тиадиазолов $\quad$ и $\quad 7$-гетарил[1,3,4]тиадиазоло- [2,3-c]- [1,2,4]-триазинов, проявляющих фунгицидную активность // Журнал органической химии. 2007. Т. 43, вып. 12. C.1813-1818.

5. Синтез $\mathrm{N}$-ацилированных производных некоторых триазинов / Файзуллина С.Р. и др. //Башкирский химический журнал. 2012. Т. 19, №3. C. 92-94

6. Несимметричные триазины. Взаимодействие хлорацетилхлорида с аминогуанидином и семикарбазидами / Сэйнт-Клэр Э. и др. // Материалы VI Международной научнотехнической конференции «АСФ-2002». Уфа, 2002. С.204-205.

7. Галиева Д.Р., Инграм И.Ш., Аминова Г.К. Спектральные характеристики аминопроизводных // Материалы XXI Международ. науч.-техн. конференции «Реактив-2008». Уфа: Реактив, 2008. С.78-80. 


\section{Information about authors}

\section{Сведения об авторах}

S.R. Faizullina, Post Graduate Student, FSBEI of HPE "Ufa State Petroleum Technological University", Ufa, Russian Federation

Файзуллина С.Р., аспирант, ФГБОУ ВПО УГНТУ Уфа, Российская Федерация

D.R. Sadykova, Candidate of Technical Sciences, Associate Professor of the Chair "Applied Chemistry and Physics" FSBEI of HPE "Ufa State Petroleum Technological University", Ufa, Russian Federation

Садыкова Д.Р., канд. хим. наук, доц. кафедры «Прикладная химия и физика» ФГБОУ ВПО «Уфимский государственный нефтяной технический университет», Уфа, Российская Федерация

M.S. Klyavlin, Doctor of Chemical Sciences, Professor of the Chair "Water Supply and Water Disposal" FSBEI of HPE "Ufa State Petroleum Technological University”, Ufa, Russian Federation

Клявлин М.С., д-р хим. наук, проф. кафедры «Водоснабжение и водоотведение» ФГБОУ ВПО УГНТУ Уфа, Российская Федерация

D.U. Rysaev, Candidate of Technical Sciences, Associate Professor of the Chair "Applied Chemistry and Physics" FSBEI of HPE "Ufa State Petroleum Technological University", Ufa, Russian Federation

Рысаев Д.У., канд. техн. наук, доц. кафедры «Прикладная химия и физика» ФГБОУ ВПО УГНТУ Уфа, Российская Федерация

A.K. Mazitova, Doctor of Chemical Sciences, Professor of the Chair "Applied Chemistry and Physics" FSBEI of HPE "Ufa State Petroleum Technological University”, Ufa, Russian Federation

Мазитова А.К., д-р хим. наук, проф. кафедры «Прикладная химия и физика» ФГБОУ ВПО УГНТУ, Уфа, Российская Федерация

e-mail: sveta-mol86@mail.ru 